\title{
Allusion and ekphrasis in Winckelmann's Paris description of the Apollo Belvedere
}

Article

Published Version

Harloe, K. (2007) Allusion and ekphrasis in Winckelmann's Paris description of the Apollo Belvedere. The Cambridge Classical Journal, 53. pp. 229-252. ISSN 1750-2705 Available at https://centaur.reading.ac.uk/6226/

It is advisable to refer to the publisher's version if you intend to cite from the work. See Guidance on citing.

Publisher: Cambridge Philological Society

All outputs in CentAUR are protected by Intellectual Property Rights law, including copyright law. Copyright and IPR is retained by the creators or other copyright holders. Terms and conditions for use of this material are defined in the End User Agreement.

\section{www.reading.ac.uk/centaur}

\section{CentAUR}

Central Archive at the University of Reading

Reading's research outputs online 


\section{ALLUSION AND EKPHRASIS IN WINCKELMANN'S PARIS DESCRIPTION OF THE APOLLO BELVEDERE}

As Vout (2006) has recently reminded us in this journal, Johann Joachim Winckelmann's History of the art of antiquity (Geschichte der Kunst des Alterthums, 1st ed. 1764) is widely considered to be a foundational text in the history of art. Advertising itself as the first 'systematic' account of ancient art in relation to its geographical, social and political circumstances, Winckelmann filled out the wellknown Plinian chronology of artists with a new analysis in terms of a succession of period styles, providing a satisfyingly scientific justification for the preference his contemporaries were beginning to accord to the art of the Greeks. Small wonder then that the book was lauded as a classic as soon as it appeared in Germany and was quickly translated into French and Italian. ${ }^{1}$ Nevertheless, it is also hardly surprising that this text, which promised nothing less than a 'new paradigm' for the study of antique culture, has always presented problems to its readers. ${ }^{2}$ These are partly caused by its magnitude of ambition. Titled, first and foremost, a 'history', Winckelmann's magnum opus in fact attempts to be many things: part systematic exploration of the social and physical factors that condition the development of all art; part impassioned disquisition on the essence of beauty; part antiquarian catalogue of the greatest surviving works of Greek and Roman art; part manual of aesthetic taste for aspiring contemporary artists. Few books since Winckelmann's History can have combined bold claims about their importance as historical scholarship with detailed instructions on how to draw a perfectly beautiful face.

A particular stumbling-block for readers of the History has been the set-piece descriptions of famous antique statues that punctuate the second, more 'historical' part of the book: extended portraits of the Niobe group from the Villa Medici and of the Laocoön, Torso, Apollo and Antinous from Vatican's Cortile del Belvedere. ${ }^{3}$ These lyrical evocations of what were then held to be among the highest achievements of ancient art form memorable digressions in the History's narrative; nevertheless, Winckelmann's inclusion of what appear to be highly emotional reports of his own responses to these statues has also been seen as dubious in a book that purports to offer a history: a true account of the past. ${ }^{4}$ Prettejohn (2005) articulates well the problems these passages pose even to a reader sympathetic to Winckelmann:

1 For details of the translations cf. Vout (2006) 139 n. 1. For Winckelmann's early French reception cf. Pommier (1989).

2 For the History as offering a 'new paradigm' cf. Potts (1994) 11-46.

3 Cf. Winckelmann (1964) 7 for the designation of Part two as 'history of art in the stricter sense'.

4 Cf. Winckelmann (1964) 16-17. 
Winckelmann interrupts the smooth chronological flow at intervals to introduce a striking description of an existing work of ancient art, or more precisely a dramatic account of his own experience of such a work. Abruptly, at these points, the perspective shifts away from scholarship, from history, from the past tense, from third-person narrative. Suddenly the emphasis is on the visual, on the present, on the singularity of the work rather than its position in a historical sequence, on the way 'I' (Winckelmann) experience it rather than on its objective properties. ${ }^{5}$

As Prettejohn recognises, this imaginative, first-personal perspective is necessitated by Winckelmann's aim of constructing a continuous historical narrative in the face of the uneven evidence provided by extant texts and material remains. Yet his reliance upon the aesthetic sensibility of an individual, modern observer appears to be of problematic historicity, leaving the way open for some critics to dismiss his conclusions as mere subjective value-judgements - or worse still, the sublimated expression of erotic preferences. ${ }^{6}$

Unease about these sections of the History is not simply a symptom of modern readers approaching Winckelmann's text with anachronistic expectations. Many eighteenth-century readers of the History found them just as difficult. Winckelmann's descriptions were utterly unlike anything they were accustomed to find in works of antiquarian scholarship. Here, for example, is the entirety of the description of the Apollo Belvedere given by Jonathan Richardson, whose book is singled out in Winckelmann's Preface as 'its many omissions and errors notwithstanding, the best that we have':

The Apollo. The Face is intire, and the Head was never broken off. (My father has a Cast of the Bust, and a Drawing of the Head by Guido). The Right-leg has been broken in pieces, and not having All 'tis ill set together again, and what was wanting supply'd with Mortar; the Left-leg is damag'd from the Knee to the Foot, and repair'd also with Mortar, but looks ragged; and but one Finger remains on the Right-hand. 'Tis in Perrier (No. 30) and in several other Books of Statutes, as Biscop's, Rossi's, \&c. He has just discharg'd his Arrow at the Python, and has an Air, particularly in the Head, Exquisitely Great, and Awful, as well as Beautiful. ${ }^{7}$

Richardson agrees with Winckelmann's interpretation of the Apollo's iconography, and his closing comment hints at the statue's impact on the viewer. Beyond this, however, their descriptions could not be more different. Richardson's is brisk, focussed upon identification of individual restorations rather than the impression made by the whole; and the tone is authoritatively impersonal, with none of the intense selfreference of Winckelmann's account.

5 Prettejohn (2005) 18-19.

6 Cf. e.g. Ettlinger (1981), Donohue (1995).

7 Richardson (1722) 275-6, cf. Winckelmann (1964) 10. 
Somewhat closer to the latter is Joseph Spence's Polymetis, a work also cited more than once in the History. ${ }^{8}$ Spence, who between 1828 and 1838 had been Professor of Poetry in the University of Oxford, sought to 'enliven' his antiquarian subject-matter by casting it into a dialogue in which the eponymous protagonist conducts two friends around a gallery of antique representations of gods. ${ }^{9}$ This format gave scope for portraying subjective response, which is indeed conveyed in Polymetis' introductory comments (in the chapter on Apollo) that 'the air of the Apollo Belvedere, gives us an idea of something above human' and contains 'a grace resulting from the whole, which is much more easily felt than described'. ${ }^{10}$ When it comes, however, the description of the statue is just as matter-of-fact as Richardson's:

As to his particular character, you see it is the Apollo Venator. But tho' he presides over the chace, and seems actually engaged in it, he is dressed rather too fine for his character. His hair is in some sort dressed; and collected together a little above his forehead. His Chlamys, which is only fastened with a gem over his breast, falls loosely down his back, and is tossed over his arm. His feet are in one sort of fine buskins, which they used antiently for the chace. All the rest of his body is naked. In short he is, in every thing, just as Maximus Tyrius has described him: 'The god, in the bloom of youth; almost all naked, tho' he has a Chlamys over his shoulders: holding his bow; and seeming not only going to move on, but to move on rapidly. ${ }^{11}$

Winckelmann's descriptions were, then, unprecedented, and they split the opinion of their early readers. Christian Gottlob Heyne attacked them as the product of an 'overheated power of imagination' gripped by 'the sickness of omen-interpreting and prophecy', and called for a complete revision of the second part of Winckelmann's History. ${ }^{12}$ A similar line was taken by Friedrich August Wolf, who otherwise sought to defend Winckelmann against some of Heyne's sharpest criticisms. ${ }^{13}$ Nor indeed was negative or ambivalent response confined to philologists of the academy. It is also evidenced in the reaction of the German poet and critic Christoph Martin Wieland, who in 1779 published the Italian antiquarian Bracci's attack on Winckelmann as a useful warning to those who took his 'Enthusiasmus' as their model for the study of art. ${ }^{14}$

8 Most notably at the end of the Apollo description: cf. Winckelmann (1964) 310.

9 Spence (1747) iv.

10 Spence (1747) 83, 84.

1 Spence (1747) 87-8.

2 Heyne (1963) 24.

3 Wolf (1969).

14 Wieland appends his own ambivalent comment on Winckelmann to the critique, which appeared in Der teutsche Merkur: 'One can be a man of genius and very much steeped in the ancients, and pindarise with the utmost enthusiasm over the Vatican Apollo, and so forth, and yet be far inferior in antiquarian learning to someone else, who is neither a genius nor able to pindarise over any subject-matter' (Wieland (1779) 249-50). Further reactions are canvassed in Zeller (1955) and Seeba (1982). Unless otherwise indicated, all translations from Greek, Latin and German in this article are my own. 
The questions posed by the descriptions are only sharpened when we consider that Winckelmann did not adopt their distinctive mode in his earliest written accounts of the Belvedere statues. A manuscript containing descriptions of the Apollo and Torso in Winckelmann's hand is preserved in the library of the Società Colombaria in Florence. ${ }^{15}$ The following is a representative extract of the Apollo description, which covers four manuscript pages:

The thighs are strong but almost a little too round. The knees are not particularly large, and thereby suggest well the fine bone-structure of a divinity. The legs are most noble in shape, although a little round in circumference. The feet are very beautiful, however they appear somewhat unmatched ... The arms are of beautiful and slender shape: the higher hand is restored, but only a few fingers of the other are new. The inside of the antique hand is not truly beautiful, for the lines are rather too round and lack strength. The clothing is represented very finely, although lacking great beauty in its draping. ${ }^{16}$

First published by Justi (1871), this manuscript caused consternation among Winckelmann scholars owing to the marked differences in content and tone between it and the descriptions of the History. In its detailed physical observation and its concern with reporting additions and restorations, this account resembles the mode of statuedescription employed by Richardson and Spence far more than the rhapsodies of Winckelmann's published work. The opinion of the statues expressed in these notes is, moreover, more critical than anything to be found in his later writings. Such observations led Justi to suggest that the manuscript represents in large part the work of Winckelmann's friend and sometime mentor, the painter Anton Raphael Mengs: a conclusion also accepted by Potts (1980). Schadewaldt (1968) defends Winckelmannian authorship, arguing that the descriptions display subtle continuities in length and focus with the History's later treatments. Regardless of the extent of Mengs' input, the manuscript confirms that the more conventional mode of statuedescription exemplified by his predecessors was a 'live' option for Winckelmann's own work. His subsequent rejection of it in favour of the style adopted in the History must be seen as a deliberate choice.

Some promising recent approaches have posited sophisticated connections between Winckelmann's art-historical concerns and more personal preoccupations. Potts (1994) and Vout (2006) have sought to relate the tensions and dissonances of his descriptions to the ideals and anxieties attendant upon his self-positioning among cultured élites at Rome. The disruptive force of his lyrical and erotic evocations of the male nude undercuts the objective pose and cool schematising of the History's grand narrative,

15 Archivio Nr. IV-II-II-52. The manuscript probably dates from early 1756, when Winckelmann's letters to friends announce that he and Mengs are undertaking a joint work 'Of the taste of Greek artists', which will include descriptions of the Belvedere statues. Cf. Winckelmann (1952) 212, 213-14.

16 Winckelmann (1968) 271. 
testifying to a deep-seated and implicitly acknowledged vision of antiquity as a site of sexual as well as socio-political liberation. This paper takes an initially rather different route into exploring of Winckelmann's descriptions: the examination of yet another early description of the Apollo Belvedere. ${ }^{17}$ This manuscript, which survives among Winckelmann's papers in Paris, has been known to scholars since the early nineteenth century; but has not received as much attention as the final version and is virtually ignored in the English-language secondary literature on Winckelmann. Yet the manuscript is interesting not only because it preserves what is recognisably a draft of the History-description written some eight years before that work was published, but also because it contains marginalia in Winckelmann's hand that give details of the sources he drew upon when composing it. ${ }^{18}$ In what follows I lay emphasis upon what the form and content of the draft suggest about the role(s) allusion to various genres of classical literature plays within the description. I will argue that attending to the generic characteristics of Winckelmann's allusions is significant for how we interpret the style of the description and its place within the History.

\section{i. The Paris manuscript}

Winckelmann's manuscripts were brought from Rome to Paris in 1798, part of the wide-ranging confiscations of cultural material made by Napoleon's forces in Italy. ${ }^{19}$ The bundles now held in the Bibliothéque nationale were catalogued by an Italian librarian in the later eighteenth century, in thematic rather than chronological order. Among the papers of volume fifty-seven, which mostly contains excerpts from various ancient and modern writers on art, are five sheets Winckelmann folded in half to make a booklet twenty pages long. On the first $(79 \mathrm{r})^{20}$ he wrote simply the letter A, followed by the one-word title 'Apollo'. With the exception of 70v, which is blank, the next ten pages $(79 \mathrm{v}-74 \mathrm{r})$ contain two drafts of the Apollo description, written on facing (verso and recto) sides of the page. Winckelmann divided each page into two columns, using the inner for his description and the outer for additions and notes. He began on 70r, and filled the inner columns of this, 71r, 72r, 73r, and the first three lines of $74 \mathrm{r}$, before crossing everything out and starting again on $79 \mathrm{v}$. The second draft fills the inner column of $79 \mathrm{v}$ and the outer of $70 \mathrm{r}$, before moving to the inner columns of 71v, 72v and 73v. Most of the marginal annotations are concentrated on

17 Fonds Allemand du Bibliothèque nationale, 57, 70r-79v.

18 Given its greater resemblance to the final version, the Paris draft was probably composed after the Florentine description. Tibal (1911) suggests that it was written between April 1756 and May 1757. A terminus ante quem is provided by letters from Winckelmann to Wille and Stosch in August 1757, which contain a version that is all-but-identical to the description of the History.

19 Cf. Décultot (2000) 303-5.

20 It seems that at time of cataloguing, the first page of this booklet was folded around to the back of the fascicle. It was therefore numbered by the cataloguer as the final folio (79). For a fuller description of the manuscript cf. Zeller (1955) 37-43. 
these three pages. ${ }^{21}$ On $73 \mathrm{v}$ the continuous prose is replaced by disconnected notes, and on $74 \mathrm{r}$ - after drawing a line and writing the title 'Description of the Apollo in the Belvedere' - Winckelmann recommenced with a characterisation of the Apollo's face. A quotation from Lucian on $74 \mathrm{v}$ is only loosely integrated into the description, and apart from another isolated quotation from Lucian on $78 \mathrm{v}$ the remaining pages are blank. The manuscript was first published (in badly edited form) by Joseph Eiselein in 1829. It was re-edited in the 1950s by Hans Zeller (with an important source-critical commentary and discussion) and again in the 1960s by Walter Rehm. ${ }^{22}$

The two descriptions contained in the manuscript are closely related both to each other and to the version in the History. ${ }^{23}$ I therefore concentrate in what follows on the second draft, which contains most of the marginalia that are my primary concern. I begin below from the aspect of the manuscript emphasised most by previous commentators: its value as further evidence of Winckelmann's well-known engagement with Homer. I then turn to a second, less well-explored set of Hellenistic and Graeco-Roman sources indicated in the notes. After a preliminary consideration of the significance of Winckelmann's use of these, I discuss the third and final group of sources attested in the marginalia: Pindar and the Homeric hymns. In the conclusion I briefly relate my arguments to some recent approaches to Winckelmann. A translation of the second Paris draft follows in the Appendix.

\section{ii. Iliad and Odyssey}

As I have mentioned, previous discussions of classical allusion in the Apollo description have concentrated - with good reason - on Winckelmann's debts to Homeric epic. Winckelmann was an ardent admirer of Homer, whom he tended to call the 'god-like' or 'divine' poet (der göttliche Dichter) - this in itself a tribute to familiar Homeric epithets such as dios and theoeides. Notable among the many excerpts from the Iliad and Odyssey to be found in his notebooks are a set of around three hundred verses compiled during his Seehausen years (1743-8), together with an original Latin epigram in which he invokes the Muse's aid in increasing Homer's renown throughout the German lands. ${ }^{24}$ Mengs' well-known portrait, painted shortly after Winckelmann's arrival in Rome in 1755, shows the budding connoisseur holding a copy of the Iliad; and the History's version of the Apollo description twice likens the statue to Homer's 'images' of gods. ${ }^{25}$ Kraus (1935), Schadewaldt (1941, 1968) and especially Zeller (1955) have given valuable analyses of how the vocabulary, imagery and rhythm of

21 Only one note listing sources occurs on the pages that contain the first draft: a list of testimonia to the beautiful hair of heroes on 73r. Zeller (1995) and Rehm (Winckelmann (1968)) ad loc. suggest that W's marginal note $\mathrm{f}$ may also relate to the first draft. Cf. $\mathrm{n}$. 39 below.

22 Eiselein (1829) 12, 64-72; Zeller (1955); Winckelmann (1968) 272-9.

23 Zeller prints a concordance of both drafts and the History in the margins of his text.

24 Cf. Kraus (1935) 1-17, Schadewaldt (1941) 14-44.

25 Winckelmann (1964) 309. 
Winckelmann's description evoke the Homeric poems. I will therefore confine myself to indicating some of the more notable Iliadic and Odyssean resonances in the Paris draft.

These associations are, if anything, more explicit than those in the final version. Winckelmann's intention to incorporate Homeric allusion into his description is signalled explicitly at the bottom of 70r, where an interlinear note announces 'here the description of Apollo from the first book of the Iliad is still to be introduced'. As Zeller realised, this refers to $I l .1 .43-54$ and Apollo's descent from Olympus to send plague upon the Greek ships. ${ }^{26}$ The account of the statue that follows $(71 \mathrm{v}-72 \mathrm{v})$ is built around an extended simile in which its youth and beauty are likened to the Elysian fields: a comparison that survives (albeit in truncated form) in the final version. ${ }^{27}$ Zeller connects this passage to Proteus' description of Elysium at Od. 4.566-8, but the characterisation of Alcinous' fruit-groves at $O d$.7.112-21 provides an even closer parallel. As much as any particular content, though, it is the use of extended simile itself that evokes the Homeric poems. The simile's length, its comparison of something abstract (youth, beauty) to something more concrete (a garden), and its elaboration of details of the vehicle beyond those that correspond to the tenor place it in the province of Homeric epic.

Indeed, this whole section of Winckelmann's draft may justly be said to have an epic character. The Paris description contrasts notably with the Florentine version in containing little detailed comment on the statue's physical characteristics. Instead of close observation of the relative length of toes and the curvature of hand and thigh, Winckelmann offers an interpretation of the Apollo in terms of a segment of mythical narrative. The main effect the description creates is that of motion, as Apollo's pursuit of the Python leads him to run across and indeed almost off the page. This bears no resemblance to earlier eighteenth-century descriptions of the statue. It does, however, recall the famous ekphrasis of Achilles' shield at Il. 18.468-617, on which the figures move and take on life in just this manner.

\section{iii. Ekphrasis beyond the Iliad: epigram and Philostratus}

Previous commentators upon the Paris Apollo description have tended to play down the presence in it of ancient models other than Homer. ${ }^{28}$ There can be no doubt of Winckelmann's particular admiration for Homer; nevertheless, to concentrate exclusively on his Homeric allusions would be overlook the significance of another set of amply-attested sources. This group encompasses a variety of Hellenistic and Graeco-

26 Winckelmann copied out this passage in his Florentine notebooks, in conjunction with the earliest Apollo description. Cf. Zeller (1955) 61-2.

27 Winckelmann (1964) 309. The motif of the 'eternal springtime' of Elysium is a commonplace in archaic poetry. Another example from a poet Winckelmann read carefully is Pind. Ol. 2.68-75.

28 For example, Kraus comments that the other 'borrowings' attested in the marginalia are 'only sporadic', concluding that they furnish evidence more of extensive reading than of the 'spiritual assistance' Homer provided. Schadewaldt agrees, emphasising that for Winckelmann, only Homer sufficed to express the grandeur of the Apollo. Cf. Kraus (1935) 38, 49; Schadewaldt (1941) 33-6, 55-7. 
Roman writings: epigram, the elder Pliny, Pausanias, Lucian, and the elder Philostratus. The common thread linking this otherwise rather eclectic collection is that, with very few exceptions, the passages Winckelmann cites all derive from a single compendium: the seventeenth-century Dutch philologist Franciscus Junius the Younger's treatise De pictura veterum (Of the art of the ancients). ${ }^{29}$ Winckelmann made the purchase of this book a priority during his first year at Rome. He eventually acquired a copy of the second (1694) Latin edition, which united De pictura with the same author's Catalogus or lexicon of ancient artists and their works. ${ }^{30}$ Junius' two books together provide a cornucopia of ancient testimonia that, according to its modern editors, still constitutes 'the most liberal, the most committedly loving, and by far the most exhaustive presentation of the literary sources of classical art.' 31 It is therefore unsurprising that Winckelmann turned to Junius for his study of ancient sculpture; but the passages gleaned from his reading are woven into the description in ingenious ways.

The marginalia to $71 \mathrm{v}$ reveal that the immediate inspiration for the movement of Winckelmann's Apollo is furnished not by the Iliadic shield, but rather by a passage from Pausanias that bears witness to the god's athletic prowess, together with the following epigram from the Planudean Anthology:

As you were in life, Ladas, fleeing wind-swift Thumos, treading on toe-tips of wind,

just so did Myron cast you in bronze, stamping all over your body the expectation of Pisa's crown.

He is full of hope, on the tips of the lips breath appears from within the hollow ribs.

The bronze leaps swiftly for the garland, and is not held back by the base. $\mathrm{O}$ art, swifter than wind!32

Winckelmann's Apollo proceeds 'swiftly and easily, as if on wings of wind', a comparison drawn no fewer than three times in this short poem. ${ }^{33}$ But what is most

29 Winckelmann's citations from Pausanias and Lucian do not occur in Junius (although the latter does quote these authors frequently). It is unsurprising that Winckelmann ventured beyond Junius in these cases. His letters of 1755-6 announce that Pausanias is one three authors (the others are Pliny and Strabo) he is rereading in their entirety as part of his study of ancient art, and his notebooks show that he read extensively in Lucian alongside these authors. Cf. Winckelmann (1952-7) 1. 197-8, 201-2, 208; Décultot (2000) 241,253 . Cf. sec. iv below for discussion of the Lucianic marginalia.

30 Cf. Winckelmann (1952-7) 1.209, 274-5, 308. I cite Junius (1694) by $C$ (for Catalogus) or $P$ (for De pictura) followed by page number. Wherever possible I quote from Junius' own 1638 English translation, giving book, chapter and paragraph numbers in brackets after the page reference. It should be noted that this edition differs from the Latin in some respects, not least its omission of the entirety of book 3, chapters 8-11.

31 Aldrich et al. (1991) xiii-xiv.

32 A.P. 16 (Plan.) 54, cited in Winckelmann's note d. Neither Winckelmann nor Junius cite Greek epigrams from any source other than Planudes, which formed the main route of familiarity with the genre until the nineteenth century. Cf. Cameron (1993) 17, 164-201.

33 There are Homeric precedents, for example Od. 7.36's characterisation of the Phaeacians' ships as swift as 'a winged creature or a thought'. 
striking about the epigram is that in it, preternatural speed is attributed not only to Ladas, the athlete who forms the subject of the representation. It is also ascribed to the object or medium of representation: the bronze statue itself. As in Winckelmann's description, the statue comes alive under the viewer's (or poet's) gaze.

Insistence upon the animate qualities of an inanimate object is in fact a recurrent topos in ancient ekphrases of works of art. The category of 'ekphrasis' has recently received a great deal of critical discussion, which has corrected and extended the common use of the term to denote 'a verbal representation of a visual representation'. ${ }^{34}$ Webb (1999) invokes the discussions of the ancient rhetorical manuals known as Progymnasmata to reject this definition on two counts. It is, first, too narrow, as the ancient discussions define ekphrasis simply as a form of descriptive speech that is 'vivid/visible' (enarges) and 'brings what is to be shown before the eyes'. Ekphrasis is therefore characterised primarily in terms of its effect on its audience, rather than by reference to any particular subject-matter. Second, such discussions list the possible subjects of ekphrasis as persons, places, times, events, and may also include other categories such as plants or animals, but works of art are never identified as a distinct category. In privileging descriptions of works of art, the common understanding is therefore also actively misleading.

Elsner (2002) agrees with Webb's criticisms of the narrowly restrictive definition and proposes an alternative, formal classification of ekphrases as either 'interventive' (passages of description or descriptive narrative embedded in longer narrative texts, such as epic poems), or 'self-standing' (the most prominent category of which is furnished by ekphrastic epigram). This categorisation allows him to sketch the development of both types from their beginnings in archaic poetry through to their intense cultivation during the Second Sophistic, and to argue that from the shield of Achilles onwards, descriptions of works of art form 'always a subset of the wider ancient definition of ekphrasis, but always also a special and outstanding set of cases'. 35

From this perspective, it is possible to explain ancient ekphrases' characteristic and emphatic astonishment at the verisimilitude of artistic representations (so life-like that they seem actually to breathe and move!) as an aspect of the vividness (enargeia) insisted upon in the ancient discussions. ${ }^{36}$ Transparency of both verbal and visual representation, such that the listener imagines she can see the subject depicted by the statue that is being described, is the promise of the kind of description that, in the words of one ancient discussion, attempts 'through hearing almost to bring about seeing' ${ }^{37}$

34 This much-quoted definition is from Heffernan (1993) 3.

35 Elsner (2002) 2, 14. For an example of a treatment of ekphrasis from the Progymnasmata, cf. Hermog. Prog. 10, translated in Elsner (1995) 25. Further discussions include Fowler (1991), Goldhill (1994) and (2001), Zeitlin (2001), Elsner (2000) and the contributions to special issues of Word and Image (1999) and Ramus (2002).

36 The locus classicus for discussions of enargeia (illustratio, evidentia) is Quintilian 6.2.26-36. Cf. too the emphasis in Arist. Rh. 3.11.2 on describing inanimate things as if animate as a means to vividness.

37 Hermog. Prog. 10.24-5. 
The Paris marginalia reveal that in his adoption of this topos Winckelmann engaged with ancient ekphrastic traditions far beyond the Iliadic Shield. In addition to ekphrastic epigram, the pretence of animation is central to the mode of description employed by the elder Philostratus throughout his Imagines, a text that played a crucial role in shaping ideas about ancient wall-painting from the Renaissance until the excavations at Pompeii and Herculaneum in Winckelmann's day. Time and time again, Philostratus' descriptions of paintings bring their subjects to life, giving us revellers whose carousing can be heard, a dying youth still 'breathing of the palaestra', a garden whose fragrances can be smelled, and (perhaps the closest parallel to Winckelmann) huntsmen who threaten to rush past before they can be described.38 Philostratus is cited in Winckelmann's note f: a catalogue of sources for the well-formed noses of heroes that is drawn straight from Junius. ${ }^{39}$ But Winckelmann's description shares further features of style as well as content with the ancient author.

A particularly striking resemblance is his call to the reader to 'Look' (71v), a command that holds out the promise of transgressing the limits of verbal representation at the same time as it calls attention to its impossibility. The injunction to 'look' ('hora', 'idou') recurs in many of Philostratus' descriptions. ${ }^{40}$ The trope may be felt to be less mannered in the ancient author, as the opening of the Imagines establishes a narrative context in which the speaker is guiding an attentive internal audience around a lavishly decorated Neapolitan villa. Winckelmann's descriptions never define their audience quite so explicitly; yet in many of them he too adopts the role of periegete. ${ }^{41}$ This is clearest in the version of the Torso description published in 1759 in the German literary journal, Bibliothek der schönen Wissenschaften und der freyen Künste. The description, which begins 'I lead you now to the oft-celebrated but never sufficiently praised torso of Hercules ...', is prefaced by the pious (and patently falsely modest) wish that someone better-qualified than Winckelmann might undertake similar presentations of other statues, as they would be 'indispensable for the instruction of young artists and voyaging connoisseurs' ${ }^{42}$ In the final version of the Apollo description, the fantasy of physical proximity to the statue is also suggested in Winckelmann's comment that 'in the sight of this wonder of art I forget all else, and I myself take up an elevated stance in order to look upon it with worthiness'. ${ }^{43}$ The present tense invokes a context in which

38 Cf. Philostr. Imag. 1.2, 1.4, 1.6, 1.28.

39 Junius (1694) 251 (3.9.231). Although Winckelmann's note occurs mid-way through the text of the second draft, it appears to relate a passage of the first draft (73r 2-7): "Anger bristles in his nose and scorn sits upon his lips: but his eye is like the eye of he who made Olympus shake and it hovers in an eternal calm as if on the surface of a still sea.' See below for emphasis on the beauty of a combination of emotion/pain and stillness as a parallel between Philostratus and Winckelmann.

40 'Hora' occurs fifteen times in the course of the sixty-five descriptions. The second person singular present indicative is also frequent, usually in the form of the question 'Do you see X'? 'Idou' occurs thirteen times. On the importance of this trope in Philostratus cf. Elsner (2004) 163.

41 This aspect of Winckelmann's ekphrases is emphasised by Morrison (1996), who fails to note the ancient precedents.

42 Winckelmann (1968) 169.

43 Winckelmann (1964) 310; cf. n. 76 below. 
the viewer stands before the Apollo, a context entered into vividly in the speaker's imagination.

Given that Winckelmann's engagement with Philostratus has received little attention, it is interesting to note a further affinity between their writings. What appears in Winckelmann as an almost pathological insistence upon an aesthetic that celebrates a combination of violent emotional expression and deathly stillness is also reminiscent of Philostratus. Alex Potts has drawn attention to this aspect of Winckelmann's statuedescriptions, which reaches its zenith in his commentaries on the Niobe and Laocoön. ${ }^{44}$ The beauty Winckelmann finds in these depictions of death and suffering is comparable to Philostratus' ekphrasis of the suicide of Panthea: one of his most celebrated descriptions, which happens also to be among those cited in Winckelmann's note:

She has already driven the dagger through her breast, but with such fortitude that she has not uttered even a groan at the thrust. At any rate she lies there, her mouth retaining its natural shapeliness and by Zeus a beauty the bloom of which so rests upon her lips that it shines forth clear, silent though she is. She has not yet drawn out the dagger, but still presses on it, holding it by the hilt - a hilt that resembles a golden stalk with emeralds for its branches - but the fingers are more charming still; she has lost none of her beauty through pain ...45

\section{iv. Ways of viewing: Junius and Lucian}

Via a consideration of the marginalia in the Paris draft, I have so far sought to show that the distinctive style of Winckelmann's Apollo description attests to his extensive use of ancient literary sources in its composition. This engagement ranges beyond his better-known Homeric borrowings to embrace various Hellenistic and Graeco-Roman writings on art. Before following the trail of Winckelmann's classical allusions any further it is worth pausing to consider in a preliminary fashion what the function(s) of this allusive practice might be.

While the earlier twentieth-century commentators cited above tended to stop at attributing the style of Winckelmann's Apollo description to the intensity of his response to the statue, ${ }^{46}$ Jeffrey Morrison's important 1996 discussion has demonstrated the fruitfulness of situating Winckelmann's writings within the overall programme of artistic paideia he offered selected students at Rome. Once again it is the 1859 Torso description that provides the most explicit statement of such a pedagogic goal, offering itself to its readers as:

44 Cf. Potts (1994) 1-10, 101-12.

45 Philostr. Imag. 2.9, tr. Fairbanks (1960).

46 For example, Kraus (1935) 45-6 comments that the Paris description is 'free from any purpose, an entirely self-sufficient image, respecting neither the demands of the profession of art critic nor of incorporation into a work destined for publication'. 
a trial of what there is to think and say about so perfect a work of art, and as a model for investigation into art. For it is not enough to say that something is beautiful; one should also know to what degree and why it is beautiful. ${ }^{47}$

This is echoed in a comment in the History's Preface: 'The description of a statue should show us the reason for its beauty and indicate something specific about its artistic style.' 48 Given these clues from elsewhere in Winckelmann's writings, it seems appropriate to try to relate the classical allusions of his Apollo description to educational aims. If the description is meant as a lesson in how to respond to and interpret the Apollo, how might its classical allusions aid its readers in comprehending what they see?

One at least initially plausible possibility is that the allusions imply an attempt to date the statue to the archaic or early classical period. The Apollo description began life in 1755-6, before Winckelmann had conceived of the project of writing a history of ancient art. But even his earlier plan to compose a work 'Of the taste of Greek artists' was to have involved making judgements about the dating of previously unattributed works. ${ }^{49}$ Winckelmann's description repeatedly emphasises the Apollo's greatness (Größe) and elevated or sublime (erhaben) character: the very same terms chosen in the History to characterise the 'high' style of Phidias, Polyclitus, Scopas and Myron. According to the main discussion of the high style in Part one, chapter four, these artists were the first to overcome the defects of their predecessors to produce works that were 'beautiful, elevated and grand'. Winckelmann even comments that 'grand style' furnishes an appropriate alternative title for this chapter in Greek art, as 'apart from beauty, the most noble intention of these artists appears to have been grandeur' ${ }^{50}$ The marked coincidence of terminology between this discussion and the Apollo description has fuelled the common assumption that Winckelmann thought the Apollo dated from the high period of Greek art.

An archaic or early classical provenance for the statue is supported by the citation from Pliny in marginal note e of the Paris draft: 'Pythagoras Rheginus - first to copy the sinews and veins and the blood-vessels in detail.' In the light of this note, and given that Pliny placed Pythagoras' acme in the 90th Olympiad (around $420 \mathrm{BCE}$ ), Winckelmann's comment on 71v that 'neither pulsing veins nor potent sinews heat and stir this body' turns out to be a coded message that locates the Apollo firmly in the 'high' period. The Homeric allusions may also support this picture. Although the History is silent on the question of when the Iliad and Odyssey were composed, Winckelmann includes the establishment of Homeric recitation at Panhellenic festivals in his litany of Greek cultural developments after the Persian wars, allowing them an influential role in the advancement of art to its perfection..$^{51}$ It is therefore arguable that,

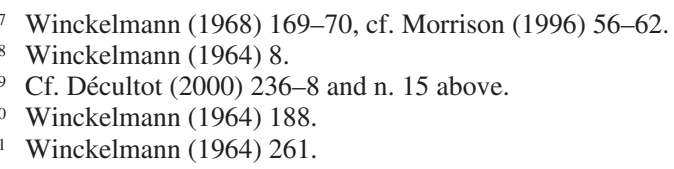


as Schadewaldt thought, Homer functions in Winckelmann primarily as a signifier for 'elevated thought' (erhabenes Denken): the grandeur of conception and execution that is a hallmark of the high style. ${ }^{52}$ The Apollo description's Homeric allusions work to reinforce the reader's sense that he is indeed confronting an object from that first great period of Greek art.

Nevertheless, not everyone has agreed that Winckelmann's description marks out the Apollo as a 'high style' work. An important exception from the consensus is Potts, who argues that the description conflates features of the high and the beautiful, collapsing the careful theoretical dichotomy constructed between the two styles of art. ${ }^{53}$ It is, moreover, problematic for this interpretation that - during the very discussion of the high style that uses terms evocative of the Apollo description - Winckelmann goes on to designate a statue of Pallas in the Villa Albani together with the Niobe group as 'the most noble and, one can say, the only works in Rome from the time of this high style, so far as I can see'. ${ }^{54}$ It is not the Apollo but the Niobe that furnishes the paradigm of the high style in the History; and the portrait of the former does not come until deep into Part two's narrative of the decline of art under the Roman empire.

Winckelmann in fact had more than one reason to hesitate before ascribing the Apollo to the period of the high style. By comparison with some other statues, he had little contextual evidence for dating it at his disposal. Unlike the Torso, no name of a sculptor was carved into the base, and in contrast to Laocoön, no identification with any statue mentioned by an ancient writer could be suggested. There were even conflicting traditions about where the statue had been dug up: Richardson claims to have seen the hole in the Horti Sallustiani from which it had been recovered, whereas Winckelmann follows an alternative tradition that located its excavation outside Rome, in Anzio. ${ }^{55}$ Moreover, by the 1750 s and 60 s some voices were beginning to dissent from the high praise traditionally accorded to the statue, not least among them Winckelmann's friend Mengs. ${ }^{56}$ Amid such uncertainties the description's Homeric allusions may nevertheless represent a kind of compromise: archaic grandeur borrowed from the poet implying that the Apollo belongs to this period while falling short of an explicit attribution.

The hypothesis of an implicit stylistic ascription therefore seems to me to have some merit; nevertheless, the eclecticism of Winckelmann's other citations must further complicate the picture. If the primary purpose of the allusions was to insinuate that the statue belonged to the high period, the inclusion of Hellenistic and Graeco-Roman sources would surely only dilute this message. This makes it worth considering the possibility that a second intention on Winckelmann's part co-existed with the desire to

52 Schadewaldt (1941) 19-21.

53 Potts (1994) 118-32. Cf. too Ettlinger (1981) 510-11, quoted at n. 77 below; Beard and Henderson (2001) 107-10.

54 Winckelmann (1964) 190, emphasis mine.

55 Richardson (1722) 276, Winckelmann (1964) 308.

56 Potts (1980). 
make a stylistic attribution: the wish to construct a context of interpretation for the statue in which a response appropriate to its ancient meaning and functions would be evoked. Rather than providing a set of cues that would encourage the reader to conjecture a historical and geographical location for the Apollo's production, to provide a context in this sense would be to delineate an imaginative situation into which she should project herself in order to respond to the statue with attitudes appropriate to its ancient contexts and modes of reception. My suggestion, in short, is that Winckelmann's description is an attempt to recreate the mode of seeing or 'visuality' of an ancient viewer of the statue. ${ }^{57}$

Such an attempt might be seen as a corollary of Winckelmann's well-known insistence on the importance of autopsy in the formation of aesthetic judgement: his claim that no amount of scholarly discussion could stand in for first-hand experience of ancient art. ${ }^{58}$ The literary style of the Apollo description represents the logical extension of this presumption to the sphere of historical inquiry. Only by recovering Greek ways of viewing can the historian come to an appreciation of the original significance of Greek art. Ekphrases of works of art would form an obvious point of reference for anyone attempting to recreate ancient visualities in this manner. As extended descriptions that also characteristically make reference to viewers' responses, they provide evidence for ancient attitudes of viewing as much as (perhaps more than) for the iconographic conventions of ancient art. Moreover, Junius - who provided Winckelmann's path to many of these authors - is unambiguous in recommending such sources as paradigms of how to appreciate art. According to his hermeneutic model (which is both clearly grounded in his reading of ancient rhetorical writers and strikingly similar to Winckelmann's), the end of artistic appreciation is the perception of that indefinable and inimitable 'grace' that is the highest achievement of great art. Development of a sensibility to this quality requires repeated and detailed observation of the best works. Just as important, however, is the capacity to respond to them imaginatively, using one's 'phantasy' to recreate and re-experience the subject of the depiction as it presented itself to the mind of artist:

... Wee should not onely goe with our eyes over the severall figures represented in the worke, but ... we should likewise suffer our mind to enter into a lively consideration of what wee see expressed; not otherwise then if wee were present, and saw not the counterfeited image but the reall performance of the thing: which having been well observed, the very picture it selfe will instantly lead us to the principall figures. 59

Junius is clear about where one should turn for lessons in this kind of judgement:

57 Cf. e.g. Nelson (2000), Elsner (2000), Zanker (2003).

58 Cf. e.g. Prettejohn (2005) 17-19. The irony that Winckelmann's emphasis on observation coexists with a highly 'literary' reading of ancient art is not lost on Décultot (2000) 217-43.

59 Junius (1638) 341 (3.7.5), cf. too 76 (1.5.5). 
The true way now to consider pictures and statues, is most plainly set downe in the books of Images made by the elder and younger Philostratus, as also in Callistratus his Description of statues: whosoever readeth their workes with attention, shall questionlesse find his desire fully satisfied. ${ }^{60}$

Winckelmann's decision to abandon contemporary conventions of statue-description in favour of ancient modes of viewing may therefore have been prompted by Junius, but it is also in evidence at those points in the Paris draft where he goes beyond the older scholar. One such moment is his use of Lucian's dialogue Pro imaginibus, a work cited rarely by Junius but quoted (without attribution) in Winckelmann's note k. ${ }^{61}$ Together with its partner-work, Imagines, this dialogue plays upon the genre of ekphrases of works of art. ${ }^{62}$ In Imagines, the protagonist Lycinus and his interlocutor Polystratus invert the usual priorities of the genre in their construction of a verbal picture of a 'real' woman by comparing successive parts of her body to different statues of goddesses. In Pro imaginibus, Polystratus reports that the woman (by now identified as the Emperor's mistress Panthea) objects to such immoderate and potentially blasphemous praise. This prompts Lycinus to offer an extended apologia for his comparisons, a central pillar of which is the invocation of Homeric precedent. Although not itself offering an ekphrasis, Pro imaginibus explores the conventions of ekphrastic description in highly self-conscious fashion, drawing out and questioning some of its characteristic tropes. One of the precedents Lycinus ostentatiously invokes is $\mathrm{Il}$. 2.478-9, where Homer likens Agamemnon 'in eyes and head to Zeus, to Ares in waist, and in chest to Poseidon, taking the man apart limb from limb to compare him with so many gods' ${ }^{63}$ Winckelmann adopts exactly this 'dismembering' technique for his characterisation of the Apollo's face on 74r of the Paris draft, a passage retained in the final version. 64

\section{v. The hymnic framework}

I have so far argued tentatively that - alongside a possible implicit stylistic attribution - the extensive classical allusions of Winckelmann's Apollo description should be seen as an attempt to recreate the mode of seeing or visuality he found in ancient writings on art. With this suggestion in mind I now turn to the final group of sources revealed by the Paris draft. While the central portion of the description - what we might perhaps now term the 'ekphrasis' itself - encodes multiple allusions to Homeric epic as well as

60 Junius (1638) 342 (3.7.6), cf. too 304 (3.7.8).

61 Junius cites only two passages from Pro imaginibus, neither of which is the one Winckelmann quotes. Cf. Junius (1694) C 76, $C 157$ (= $P$ 132).

62 For discussions cf. Steiner (2001) 295-305, Goldhill (2001), Zeitlin (2001), Vout (2007) 213-39.

63 Lucian, Pro.im. 25.3-7.

64 Winckelmann (1964) 309-10. 
Hellenistic and Graeco-Roman sources, this section is set within a narrative framework that claims allegiance to Pindar and the Homeric hymns as much as to the Iliad or Odyssey.

The draft begins with a proem in which the magnitude of the undertaking - the description of a superlatively beautiful statue - is announced. The reader then receives a warning, commanding him to prepare himself before 'stepping forward' to the sight of the god. Greek and Latin literature furnish numerous examples of such prorrhetic proclamations in ritual or quasi-ritual contexts, ${ }^{65}$ but two perhaps particularly relevant to Winckelmann are the openings of Callimachus' Hymn 2 (to Apollo) and Horace Carm. 3.1: both poems Winckelmann knew. ${ }^{66} \mathrm{We}$ are next treated to an account of the effect the statue had upon Winckelmann himself: what is presented as a snapshot of his own feelings upon first viewing it. This passage comes towards the end of the History's version, but in this draft it is more prominent, forming the bridge between the proem and the ekphrasis. Compared with the final version, the reader's sense that Winckelmann is describing a unique and private event is heightened by his use of the past rather than the present tense. Even at this apparently most personal moment, however, the hymn-motifs continue:

My chest seemed to expand with veneration and to swell, and it was as if I myself adopted an elevated standpoint in order to be worthy of gazing upon it. Without notice I found myself led in spirit to Delos and the Lycian groves, places Apollo honoured with his presence, and I believed I saw the most beautiful of the gods with his bow and arrow. The Muses want to embrace him and the other gods tremble before him and when he enters among them they stand up from their seats.

Delos and Patara in Lycia were the locations of two important sanctuaries of Apollo in fifth-century Greece, and the invocation of the cult sites of the god is conventional in the hymnic context. One example is the famous hymn to the lyre in Pindar's first Pythian, which closes with a prayer to Apollo as 'Lycian lord, who rule Delos and cherish Parnassus' Castalian spring'.67 The Pindaric allusions that pepper Winckelmann's works show his familiarity with the poet, and there can be no doubt that he was one of those whose imagery Winckelmann mined for his description. ${ }^{68}$ Amid the disjointed phrases to be found on $73 \mathrm{v}$, as the draft peters out, he invokes 'the Theban poet' in the course of his search for ideas of beauty that might aid his composition. The Pythians are, of course, a particularly appropriate source for repre-

65 Cf. e.g. Eur. Med. 1053-4, Verg. Aen. 6.258-9.

66 Among the many excerpts from Horace in the Paris manuscripts, Winckelmann's citation of Carm. 3.4.62-4 is also particularly pertinent to my argument below. Cf. Zeller (1955) 58.

67 Pind. Pyth. 1.39-40.

68 See for example the tags from $\mathrm{Ol.10}$ that introduce the Treatise on the capacity for sensibility to the beautiful in art (Winckelmann (1968) 211-33), with the discussion of Davis (1996). 
sentations of Apollo, and there was a tradition of speculation that the Apollo Belvedere was indeed the classical cult-statue from Delphi, brought to Rome by Augustus. ${ }^{69} \mathrm{We}$ may therefore detect a certain Pythian colouring in Winckelmann's description; and this becomes even more apparent in the final version, when Winckelmann expands the first clause of the passage quoted above to "my chest seems to expand with veneration and to rise like those I see swollen as if by the spirit of prophecy ...'.$^{70} \mathrm{Just}$ as Pindar refrains from mentioning Delphi by name, but suggests it by the periphrasis 'Parnassus' Castalian spring', so Winckelmann alludes to the oracle indirectly.

The event Winckelmann interprets the statue as depicting - Apollo's slaying of the Python - is central to the aetiology of the Delphic shrine. It is also the subject narrated in the second half of the great Homeric hymn to Apollo, allusions to which are just as marked as those to Pindar throughout Winckelmann's description. The picture of the gods jumping up from their seats as Apollo enters Zeus's palace is a quotation of the Hymn's opening:

I shall remember and not forget far-shooting Apollo, the gods tremble as he approaches Zeus' halls: and they all rise up from their seats as he approaches when he draws his shining bow. ${ }^{71}$

Here, though, the drag of intertextuality pulls us back into the province of epic. For here the Homeric hymn itself rewrites a famous scene at $I l$. 1.533-5, when Zeus reenters his palace after his audience with Thetis and the other gods rise to their feet in awe. A note on 72v - 'Just as the head of Jupiter encompasses all its greatness, so etc.' - shows that Winckelmann also had this epic image in mind as he wrote the Apollo description. ${ }^{72}$ His characterisation of Apollo does not simply quote the words of the Homeric hymn, but also repeats and extends its poetic emulation of the Iliadic Zeus.

This section of the description also sees Winckelmann listing Apollo's attributes, another convention of hymns..$^{73}$ The god is beautiful, he carries a bow and arrow, and is associated with music and the Muses. Again, the Homeric hymn gives us the newborn Apollo claiming these attributes in front of the other gods:

The lyre will be dear to me and the curving bow, and I will prophesy to mortals the unerring will of Zeus. ${ }^{74}$

And lest we should think the hymn to the lyre at the beginning of Pindar's first Pythian is weighted towards the god of the Muses rather than of the bow and arrow, close

69 Winckelmann flirts with such an identification in the History, albeit suggesting that it was Nero who ordered its importation into Italy. Cf. Winckelmann (1964) 308.

70 Winckelmann (1964) 310, emphasis mine.

71 Hom. hymn Ap. 1-4.

72 Winckelmann's note g; cf. Hom. Il. 1.528-30.

73 This affinity is noted by Schadewaldt (1968) 13.

74 Hom. hymn Ap. 131-2. 
attention to his language will dispel this thought. When the lyre sounds out its notes, the eagle on Zeus' sceptre is sent to sleep, Ares sleeps, and all the other divinities are enchanted. Pindar calls the lyre's notes 'missiles' (rhipaisi) and a little later they are kela: another term for a ballistic weapon. ${ }^{75}$ The god of the Muses is most prominent, but the god of the bow and arrow is never far away. ${ }^{76}$

These hymnic resonances go some way towards accounting for the remarkable consensus about the Apollo description that exists among modern commentators. Kraus's 1935 judgement that it represents 'enthusiasm, ecstasy ... rapture and authentic exaltation' has been assented to by defenders and detractors alike:

His speech here is the speech of rapture ... of revelation. We can construe what had happened to him at that time in Rome in front of the statues of heroes and gods as nothing other than revelation in the sense of the Greeks: as epiphany.

The Apollo Belvedere is not discussed in archeological or stylistic terms - did Winckelmann realize that he was enthusing over a marble copy of a fourthcentury Greek bronze? - but as a theophany in terms which we can only find embarrassing.

Winckelmann formulates the experience of art as a process of 'Offenbarung' ... [He] imagines the process of induction into and revelation of the mysteries of aesthetic insight as comparable to the learning process of an acolyte.

[The] key word is enthusiasm ... one must become the mystical lover of the Apollo in order to comprehend him. ${ }^{77}$

My argument suggests that the description creates this impression for specific reasons: Winckelmann's narrative of his response to the statue is closely constructed out of poetic material provided by Greek hymns. How though do these hymnic resonances tally with the twin purposes of Winckelmann's allusive practice countenanced earlier?

The allusions could indeed support a stylistic attribution. As archaic/early classical poems, Pindar and the Homeric hymns would provide the high-style sheen required for such an implicit ascription. The second possibility is, however, the more intriguing. I suggested in section iv above that Winckelmann's classical allusions aim at recreating the visuality of an ancient viewer of the statue by constructing an imaginative context in which attitudes appropriate to its ancient mode(s) of reception would be evoked.

75 Pind. Pyth. 1.10, 12.

76 Bakker (2002) makes a similar argument about the Homeric hymn, pointing out how its terrifying opening is intra-textually balanced by the mirror-scene of Apollo entertaining the gods on the lyre at the beginning of its second half. Interestingly, Winckelmann also replicates the mingling of tenses that Bakker and others, for example Clay (1997), have noted as characteristic of these 'attributive scenes'. Winckelmann at first appears to narrate a singular, past event ('I found myself led in spirit to Delos ... and I believed I saw ...'), but, in the course of his elaboration of this epiphany, he breaks into the present ('The Muses want to embrace him ...').

77 Kraus (1935) 47, Schadewaldt (1941) 52, Ettlinger (1981) 510-11, Morrison (1996) 61-2, Décultot (2000) 113. 
Ekphrastic texts such as epigram, Philostratus and Lucian are important to this endeavour as they furnish evidence for ancient modes of viewing art. By alluding repeatedly to hymns, Winckelmann suggests more specifically that the authentic context for viewing this statue is one of worship, the appropriate attitudes those of veneration. Hymn-motifs are apposite because hymns constitute the genre of Greek literature that most readily evokes a performative context of cult. Winckelmann's description therefore encodes the claim that in order to understand this statue we must turn ourselves into festival-goers on Delos or at Delphi, singing the hymn and viewing the cult-statue.

\section{vi. Conclusion}

My argument has sought to account for the style of Winckelmann's Apollo description in terms of its allusions to various genres of ancient literature, as evidenced in the Paris draft. It might be thought that this kind of explanation, which seeks to relate the description's distinctive style to ancient literary traditions, is aimed primarily at rehabilitating Winckelmann's descriptions for the scholarly or systematic side of his project, distancing them from the concern with the disruptive and subjective that has informed recent approaches to the History. I conclude with three brief suggestions why such a 'rehabilitation' leaves the complexities and tensions others have detected in that work largely intact. First, despite my claim that ancient ekphrases served Winckelmann as sources for ancient ways of viewing, it must also be remembered that ekphrasis is never simply the re-mediation of a visual object in verbal form: a photostatic 'record of a view' presented to a reader. It is always also a dialogue between a speaker and a listener, in which the object of description is occluded as much as it is exposed by a verbal discourse that seeks to bind the other two agents together. ${ }^{78}$ The learnedness of the Apollo description is itself a carefully crafted pose, an important counter in its author's attempts at self-positioning. ${ }^{79}$ Moreover, considered in the light of Winckelmann's status as the initiator of a finegrained periodisation and historicisation of ancient art, his turn to Graeco-Roman sources for interpretation of the Apollo implicates him in contradictions as deep-seated as some of those explored by Potts and Vout. Finally, achievement of a total imaginative identification with an ancient viewer is a dream whose evident impossibility was not lost on Winckelmann, as the History's conclusion makes clear. ${ }^{80}$ These paradoxes, or ironies, all contribute to that work's well-known pathos and complex charge. ${ }^{81}$

\section{UNIVERSITY OF READING}

KATHERINE HARLOE

78 Cf. Elsner (2004), esp. 157-63.

79 Nothing makes this clearer than the way Winckelmann allowed drafts of the description to circulate across Europe from 1757 onwards. Cf. Zeller (1955) 31-5.

80 Winckelmann (1964) 336, cf. Davis (1994).

81 I am grateful to Professor Christopher Pelling and to $C C J$ 's two anonymous readers for useful criticisms of earlier versions of this article, and to Sophie Read for help in the Cambridge University Library. 


\section{APPENDIX}

I translate below the second of the two drafts of the Apollo description contained in the Paris manuscripts, together with the disconnected material of 74r, 74v and 78v. I have followed the edition of Zeller (1955), and attempted to make lexical and syntactical choices consonant with Mallgrave's 2006 English translation of the History. Angled brackets in the main text indicate passages deleted by Wincklemann. I have omitted minor deletions (such as truncated/unfinished word-endings) or slight syntactical variations on undeleted phrases, but have included all that seemed to me to have additional semantic content.

Winckelmann's marginalia are indicated in lettered footnotes, preceded by 'W:'. [Gr.] or [Lat.] at the beginning of a note indicates the original language (Greek or Latin) of the citations contained therein. For investigation of all sources cited in the marginalia, see Zeller (1955) 45-129.

\section{Description of the Apollo in the Belvedere}

$[79 \mathrm{v}]^{\mathrm{a}}$ I am undertaking to describe a work conceived by a great mind that could raise itself above what is material and executed by a hand destined for the formation of a higher nature.

Go first with thy spirit into the realm of incorporeal beauties to prepare yourself for contemplation of this image. Collect the concepts of elevated poets and seek to become a creator of a heavenly nature and when you have engendered an image inside yourself and a form more perfect than your eye has ever seen, then step forth to the image of this divinity. I seem to see you humbled in your thoughts, and the image that appeared to you in yourself is lost in the face of the one you now behold here and now, just as a dream fades when the truth appears

[70r] A sense of awe mingled with trepidation will transport you out of yourself, like Pygmalion whose image received life and movement under his hands: yes, the corporeal will take on spirit.

From what I myself sensed upon viewing this work I picture to myself the emotion of a soul that is possessed of a natural sensitivity to the beautiful and can be transported into enchantment in the face of what transcends nature.

My chest seemed to expand with veneration and to swell, and it was as if I myself adopted a more elevated standpoint in order to be worthy of looking at it. $<$ I saw more than my> Without notice I found myself led in spirit to Delos and the Lycian groves,

a W: [La.] 'The accurate imitation of statues has so many difficulties that Libanius in his Antiochan did not hesitate to assert that those craftsmen who have successfully copied antique statues have been granted something superhuman by the Gods. Jun. 211.

Minerva out of the head of Jupiter

[Gr:] I wrote with love.' 
places Apollo honoured with his presence, and I believed I saw the most beautiful of the gods with his bow and arrow. The Muses want to embrace him and the other gods tremble before him and when he enters among them they stand up from their seats.b

[71v] His build is elevated above the human and his stance bears witness to the fullness of his grandeur. An eternal springtime of youth clothes the perfect virility of this body, and the allure of the blooming beauty of favourable years plays upon the haughty structure of his limbs. As in blessed Elysium, where the north wind never causes the heads of flowers to droop, and the sultry midday-heat never scorches the air of the valleys, <tender vines with evergreen bowers mingle with olive-trees $>$ and blossom and fruit together cheer the branches of trees.

Look how with a mighty stride that nothing can evade he appears to pursue the Python, his enemy.c Now he is running and on the point of taking the <second> next stride, which it seems would snatch him from our sight: he is carried onwards so swiftly and easily, as if on wings of wind ${ }^{\mathrm{d}}$

In his thighs one sees no trace of forceful effort nor weight-bearing activity of the limbs, and his knees are like those of a creature whose foot has never trodden a hard material.e Neither pulsing veins nor potent sinews heat and stir this body,

$[72 \mathrm{v}]^{\mathrm{f}}$ it is as if a heavenly spirit that has flowed like a gentle stream has saturated every contour of this figure and is itself forming it.g

Its source is in his head and it flows back and forth with a rich excess and quintessence of forming beauties, ${ }^{\mathrm{h}}$ which here unite as the perfections of the gods did in Pandora. ${ }^{\mathrm{i}}$ $<$ The languid allure of the nymphs $>$ The tendernesses of the most beautiful years that $[\ldots]$ the stirring feeling of gentle charms

Here are the tendernesses of a youth who reveals his first feeling but with uneven glances at the nature he has left behind.

b W (interlinear note): 'N. B. Here the description of Apollo from the first book of the Iliad is still to be introduced.'

c W: 'Paus. V. p. 392. Ed. Lips. [Gr.] 'They say that among others (in the first Olympic race and contest) Apollo outran Hermes in competition, and beat Ares in the boxing.'

d W: [Gr.] 'Myron made a runner in the Pisaean contest, in which an art swifter than nature was perceived, as a delightful epigram (4.2) recounts.'

e W: [Gr.] 'Plin. 34.19 Pythagoras Rheginus - first to copy the sinews and veins and the blood-vessels in detail.'

f W (interlinear note) [La.; quotations Gr.]: 'Philostratus in his Heroicos praises a nose that is straight yet a little flared about the nostrils, when he makes not only Diomedes straight-nosed but also, when describing Patroclus, says Patroclus' nose was straight and flared about the nostrils like those of keen horses. Heliodorus too in the description of Theagenes at the end of Book II of his Aethiopica recounts [his] nose and nostrils freely drawing in air, a sign of spirit. In Philostratus, Imagines II Panthea is given nostrils placed moderately apart and furnishing a base for the nose.'

$g$ W: 'Just as the head of Jupiter in Homer encompasses all his greatness, so etc.'

h W: [La.] 'Comment on Propertii L. I. El. 8. verba: Ut caput in magnis. Just as a garland is placed before the feet of statues, whose heads it is not possible to reach because of their height, so we sacrifice with a little cheap incense \&c.'

i W: 'Juno with Venus' girdle'. 
$[73 \mathrm{v}]<$ The most beautiful youth among the thousands who appeared at Elis and on the Isthmus, ${ }^{j}$ marvelled at by the sages and the crowd; a youth whom the Springk

Seek the most beautiful youth, there where Nature forms beautiful human beings. $>1$ To what shall I compare his beauty and what in nature or art is equal to the concept of this creation! The young hero at whose beauty all the folk of Athens were astonishedm and the most beautiful among the many thousands who fought before Troy and whom Apollo himself loved

If the Theban poet had painted for us the beauty of Theseus, at which the whole folk of Athens were astonished, and believed that they were seeing the god of the Muses as he first appeared in his native land. If <as he did Thersites> Homer had painted the most beautiful young hero among the many thousands before Troy, whom Apollo himself loved

\section{[74r, 4-24] 1. Description of the Apollo in the Belvedere}

And in this face you see truly with one look the highest and most beautiful of the divinities elevated above all others as it revealed itself to the mind of the god-like poet and was presented to antiquity for veneration.

A brow like the one that was pregnant with the goddess of wisdom and that appears in Apollo at Delos and Claros, swollen by the spirit of prophecy; eyebrows after the concept of those that shook Olympus; eyes of the queen of the goddesses, clouded with majesty and the most beautiful mouth of utmost tenderness to kiss a Hyacinth from Pamfo [uncertain reading]

The displeasure $<$ that enraged the god against his enemy $>$ itself against the Python $<$ that widens the nose and opens the mouth $>$ that swells in the nose is like a sudden storm that remains in the lower areas of the air and does not disturb the upper atmosphere

[74v] The artist has presented the Apollo as he was when he had not yet loved Daphne, for he still has no crown of laurel. Cf. Lucian Dial. Deor. XV.2.

[Gr.] - and now instead of them I hold garlands.

[78v] Lucian Dial. Deor. XV.1 p. 242 T. I. Opp.:

[Gr.] HERMes. You have your hair, Apollo, and play the cithara and boast about your beauty, and I about my skill and the lyre, but then when it's time for bed we must sleep alone.

j W: N.B. 'There are a few well-known statues of Apollo to be cited.'

k W: [Gr.] 'Homer [called] the son of Peleus godlike many times. He said that Diogenes [and] the good men were images of the gods.'

1 W: 'Where do I take concepts of beauty'

m W: 'Nature would [...] me in a young Theseus at whose beauty the whole folk in Athens were astonished, as he first appeared to them and in Achilles the most beautiful among the many thousands before Troy, and whom Apollo himself loved.' 


\section{BIBLIOGRAPHY}

Aldrich, K., Fehl, P., and Fehl, R. (1991) 'Introduction: Franciscus Junius and the defense of art', in F. Junius, The literature of classical art, 2 vols., Berkeley, 1., xxi-lxxxiii.

Bakker, E. J. (2002) 'Remembering the god's arrival', Arethusa 35, 63-81.

Beard, M., Henderson, J. (2001) Classical art: from Greece to Rome, Oxford.

Cameron, A. (1993) The Greek anthology from Meleager to Planudes, Oxford.

Clay, J. S. (1997) 'The Homeric hymns', in I. Morris, B. Powell (eds.) A new companion to Homer, Leiden.

Davis, W (1994) 'Winckelmann divided: mourning the death of art history', in id. (ed.) Gay and lesbian studies in art history, New York, 141-59.

(1996) 'Winckelmann's "homosexual" teleologies', in N. B. Kampen (ed.) Sexuality in ancient art, Cambridge, 262-77.

Décultot, E. (2000) Johann Joachim Winckelmann. Enquête sur la genèse de l'histoire de l'art, Paris.

Donohue, A. A. (1995) 'Winckelmann's history of art and Polyclitus', in W. G. Moon (ed.) Polykleitos, the doryphoros, and tradition, Madison, 327-53.

Eiselein, J. (1965/1829) Johann Winckelmanns sämtliche Werke. Einzige vollständige Ausgabe, 12 vols., Osnabrück.

Elsner, J. (1995) Art and the Roman viewer: the transformation of art from the pagan world to Christianity, Cambridge.

(2000) 'Between mimesis and divine power: visuality in the Greco-Roman world', in R. S. Nelson (ed.) Visuality before and beyond the Renaissance. Seeing as others saw, Cambridge, 45-69.

(2002) 'Introduction: the genres of ekphrasis', Ramus 31, 1-19.

(2004) 'Seeing and saying: a psychoanalytic account of ekphrasis', Helios 31, 157-86.

Ettlinger, L. D. (1981) 'Winckelmann, or marble boys are better', in M. Barasch and L. Freeman Sandler (eds.) Art the ape of nature. Studies in honour of H. W. Janson, New York, 505-11.

Fairbanks, A. (1960/1931) (tr.) Philostratus Imagines; Callistratus Descriptions, Cambridge, MA.

Fowler, D. (1991) 'Narrate or describe: the problem of ekphrasis' JRS 81, 25-35.

Goldhill, S. (1994) 'The naive and knowing eye: ecphrasis and the culture of viewing in the Hellenistic world', in S. Goldhill, R. Osborne (eds.) Art and text in ancient Greek culture, Cambridge, 197-223.

(2001) 'The erotic eye: visual stimulation and cultural conflict', in id. (ed.) Being Greek under Rome: cultural identity, the Second Sophistic and the development of empire, Cambridge, 154-94.

Heffernan, J. A. W. (1993) Museum of words. The poetics of ekphrasis from Homer to Ashbery, Chicago and London.

Heyne, C. G. (1963/1778). 'Lobschrift auf Winkelmann', in A. Schluz (ed.), Die Kasseler Lobschriften auf Winckelmann, Berlin.

Junius, F. (1638) The painting of ancients, in three books: declaring by historicall observations and examples, the beginning, progresse, and consummation of that most noble art. And how those ancient artificers attained their still so much admired excellencie, London.

(1694) De pictura veterum libri tres, tot in locis emendati, \& tam multis accessionibus aucti, ut plane novi possint videri: accedit Catalogus, adhuc ineditis, architectorum, mechanicorum, sed praecipue pictorum, statuariorum, caelatorum, tornatorum, aliorumque artificium, \& operum quae fecerunt, secundum seriem litterarum digestus, Rotterdam.

Justi, C. (1871) 'Ein Manuscript über die Statuen in Belvedere', Preussische Jahrbücher 28, 581-609.

Kraus, K. (1935) Winckelmann und Homer mit Benutzung der Hamburger Homer-Ausschreibungen Winckelmanns, Berlin.

Mallgrave, H. F. (2006) (tr.) Johann Joachim Winckelmann. History of the art of antiquity, Los Angeles.

Morrison, J. (1996) Winckelmann and the notion of aesthetic education, Oxford.

Nelson, R. S. (2000) 'Descartes' cow and other domestications of the visual', in (id.) (ed.) Visuality before and beyond the Renaissance. Seeing as others saw, Cambridge, 1-15. 
Pommier, E. (1989) 'Winckelmann et la vision de l'antiquité classique dans la France des Lumières et de la Révolution', Revue de l'art 83, 9-20.

Potts, A. (1980) 'Greek sculpture and Roman copies I: Anton Raphael Mengs and the eighteenth century', JWCI 43, 150-73.

(1994) Flesh and the ideal. Winckelmann and the origins of art history, New Haven and London.

Prettejohn, E. (2005) Beauty and art, Oxford.

Richardson, J. and J. (1722) An account of the statues, bas-reliefs, drawings and pictures in Italy, France, \&c. with remarks, London.

Schadewaldt, W. (1941) Winckelmann und Homer, Leipzig.

(1968) Winckelmann und Rilke. Zwei Beschreibungen des Apollon, Stuttgart.

Seeba, H. C. (1982) 'Johann Joachim Winckelmann. Zur Wirkungsgeschichte eines "unhistorischen" Historikers zwischen Ästhetik und Geschichte', Deutsche Vierteljahrsschrift für Literaturwissenschaft und Geistesgeschichte Sonderheft 56, 168-201.

Spence, J. (1747) Polymetis: or, an enquiry concerning the agreement between the works of the Roman poets and the remains of the ancient artists. Being an attempt to illustrate them mutually from one another, London.

Steiner, D. T. (2001) Images in mind. Statues in archaic and classical Greek literature and thought, Princeton and Oxford.

Tibal, A. (1911) Inventaire des manuscrits de Winckelmann déposés à la Bibliothèque nationale, Paris.

Vout, C. (2006) 'Winckelmann and Antinous', CCJ 52, 149-62. (2007) Power and eroticism in imperial Rome, Cambridge.

Webb, R. (1999) 'Ekphrasis ancient and modern: the invention of a genre', Word and Image 15, 7-18.

Wieland, C. M. (1779) [Editor's note], in Der teutsche Merkur, 249-50.

Winckelmann, J. J. (1829) Johann Winckelmanns Sämtliche Werke. Einzige vollständige Ausgabe, J. Eiselein (ed.), Osnabrück.

(1952-7) Briefe, W. Rehm (ed.), 4 vols., Berlin.

(1964/1764) Geschichte der Kunst des Altertums. Vollständige Ausgabe, W. Senff (ed.), Weimar.

(1968) Kleine Schriften. Vorreden. Entwürfe, W. Rehm (ed.) (revised edn. 2002), Berlin and New York.

Wolf, F. A. (1969/1805) 'Winckelmann als Philologe', in J. W. Goethe (ed.) Winckelmann und sein Jahrhundert in Briefen und Aufsätzen, Leipzig.

Zanker, G. (2003) Modes of viewing in Hellenistic poetry and art, Madison.

Zeitlin, F. (2001), 'Visions and revisions of Homer', in S. Goldhill (ed.), Being Greek under Rome: cultural identity, the Second Sophistic and the development of empire, Cambridge, 195-266.

Zeller, H. (1955) Winckelmanns Beschreibung des Apollo im Belvedere, Zürich. 